ALEKSANDAR VORKAPIĆ, Ph.D. student ${ }^{1}$

(Corresponding author)

E-mail: vorkapic@pfri.hr

RADOSLAV RADONJA, Ph.D. ${ }^{1}$

E-mail: radonja@pfri.hr

DAMIR ZEC, Ph.D. ${ }^{1}$

E-mail: zec@pfri.hr

${ }^{1}$ Faculty of Maritime Studies, University of Rijeka

Studentska 2, 51000 Rijeka, Croatia
Transport Technology

Review

Submitted: 15 May 2017

Accepted: 5 Feb. 2018

\title{
COST EFFICIENCY OF BALLAST WATER TREATMENT SYSTEMS BASED ON ULTRAVIOLET IRRADIATION AND ELECTROCHLORINATION
}

\begin{abstract}
Having come into effect, the International Convention for the Control and Management of Ships' Ballast Water and Sediments of 2004 requires ships to process their ballast water in accordance with specific standards. Different processing methods require different use of ship power, thus affecting fuel oil consumption, ships' energy efficiency, and the ship economics in general. This paper presents the analysis and comparison of the economic viability of systems using two dominant ballast water treatment methods on merchant ships. The cost effectiveness of these methods, UV irradiation and electrochlorination, is compared to the standard efficiency of ballast water exchange using sequential flow method as a reference. The process efficiency is measured through fuel oil consumption on board. Taking into account possible variations in efficiency due to different designs and environmental constraints and assumptions, the findings are in favor of the electrochlorination method.
\end{abstract}

\section{KEY WORDS}

ship ballast water; ballast water treatment systems; ship energy efficiency;

\section{INTRODUCTION}

Invasive aquatic organisms have been recognized as a potential threat to marine ecosystems for more than 20 years, and the ever-continuous increase in maritime traffic is raising the potential danger of spreading of hazardous aquatic organisms and pathogens (HAOP) as well as the devastation of coastal waters.

At the International Conference held in London in February 2004, the International Maritime Organization adopted the International Convention for the Control and Management of Ships' Ballast Water and Sediments [1]. By meeting the agreed conditions, the Convention finally came into force in September 2017.

The BWM Convention defines two main ballast water management standards:
- D1 - Ballast Water Exchange Standard, which requires the exchange of $95 \%$ of the volume of ballast water using either the sequential flow method or the flow or dilution method, and

- D2 - Ballast Water Performance Standard, requiring ballast water treatment resulting with less than 10 living organisms per $\mathrm{m}^{3}$, sized $\geq 50 \mu \mathrm{m}$, as well as less than 10 living organisms per $\mathrm{m}^{3}$ of water, sized $<50 \mu \mathrm{m}$ and $\geq 10 \mu \mathrm{m}$, with a limited number of indicator microorganisms (bacteria).

Modern ballast water treatment (BWT) systems usually employ a two-step treatment approach [2].

The aim of the primary treatment process is to reduce the number of large aquatic organisms. Consequently, it considerably increases the efficiency of secondary treatment, which then reduces the amount of organic substances below the required level [3]. The primary treatment methods in use are filtration and hydrocyclone.

During filtration, ballast water is filtered by passing through a semi-permeable barrier (filter), removing particles, sediments, zooplankton, and phytoplankton larger than $50 \mu \mathrm{m}$.

The hydrocyclone separates solids (aquatic organisms) from liquids (in this case, ballast water), using centrifugal forces. Since the efficiency of the hydrocyclone greatly depends on the mass and density of the particles, this method is somewhat deficient in the removal of small organisms from ballast water.

Other physical methods of primary treatment of ballast water are coagulation with flocculation (sometimes prior to filtration to increase its efficiency) and filtration with crumb rubber. However, these two methods are not widely used in currently available ballast water treatment systems.

Secondary separation methods include a variety of physical and chemical methods, used alone or in combination $[4,5]$. The most commonly used physical methods include ultraviolet (UV) irradiation, heat, 
ultrasound, and magnetic and electrical water treatment. The chemical methods in use involve biocides, chlorine, ozone, hydrogen peroxide, chlorine dioxide, and other chemicals.

From the 55 available and IMO-approved BWT systems (BWT systems with basic authorization [6]), 20 (36\%) use UV irradiation, and 20 (36\%) use electrolysis/electrochlorination for secondary treatment, i.e., the disinfection of ballast water. Those two BWM methods are the most commonly used BWT systems on ships [7]. One of the latest systems with basic IMO approval, in addition to the standard filtration in primary treatment, combines those two methods during secondary treatment (ECS HYBRIDTM System, TECHCROSS Inc., Busan, South Korea). Interestingly, during 2014 and 2015, most of the newly approved systems or, to be more specific, seven out of ten systems approved in this two-year period, used electrolysis as a method of treatment and only one (HYBRIDTM) used UV irradiation.

Consequently, the comparison and analysis of the economic viability of those two most frequently used BWT methods (UV irradiation and electrochlorination) based on fuel oil consumption on board are presented.

\section{ULTRAVIOLET IRRADIATION AND ELECTROCHLORINATION}

Ultraviolet irradiation (UV), as a method of ballast water treatment, is based on the impact of UV rays on living cells [8, 9]. It is carried out by using low pressure or high pressure UV lamps. Low pressure UV lamps (emitting UV-C radiation light with a wavelength of about $254 \mathrm{~nm}$, the so-called 'short-wave' or 'antimicrobial' light) have the strongest effect on the nucleic acid, damaging the DNA in particular. If the cells activate the so-called 'repair mechanisms', the damage may not be terminal, which significantly influences the effectiveness of the treatment. High pressure UV lamps emit UV-A (400-315 nm, the so-called 'long-wave' or 'black light'), UV-B (315-280 nm or medium-wave light), and UV-C radiation. To some extent, implementation of UV light may create ozone, a gas with a significant biocidal effect. BWT systems using UV irradiation typically contain several UV lamps placed along the flow of ballast water. Maintenance of UV systems is relatively simple since it only requires replacement of damaged lamps or occasional cleaning of lamp sleeves.

It is essential that organisms present in ballast water are exposed to UV light long enough for DNA damage to occur [10]. Namely, if the flow is too fast, there is not enough time for UV light to affect organisms. On the other hand, if the flow is too slow, the lamps can overheat and failures may occur.

Recognizing the fact, the US regulations for ballast water quality differ from the IMO standards regarding residual organisms after water treatment [11]. They require that there should be no surviving organisms in the discharged ballast water after treatment. This is incompatible with the UV treatment method, where some organisms may survive, but with no or minimal reproduction or multiplication capabilities.

Electrolysis is an electrochemical process where direct current passing through the electrolyte (ballast water) is used to create various compounds with significant oxidation capabilities, and therefore disinfection potential. Some of those compounds are hypochlorite acid $(\mathrm{HOCl})$, hypochlorite ion $\left(\mathrm{OCl}^{-}\right)$, hypobromate acid ( $\mathrm{HBrO})$, hypobromate ion $\left(\mathrm{BrO}^{-}\right)$, and hydroxyl radicals $\left(\mathrm{OH}^{-}\right)$. [3]

Electrochlorination is a process of creating reactive chlorine compounds by electric current passing through ballast water with high salt content. The efficiency of those systems is extremely high. Research and testing of such systems recorded a destruction of 99\% bacteria, phytoplankton, and zooplankton [12]. Beside the concentration of chlorine in the water, the efficiency of the process also depends on the temperature, reaction time, and amount of any residual chlorine and its compounds. In addition, this type of ballast water treatment brings about the problem of creating the so-called 'disinfection by-products', the most dangerous of which are products resulting from the reaction of chlorine with organic material, such as chloroform, trichloronitromethane, and dichloroacetic and trichloroacetic acid. It is therefore necessary, before discharging ballast water treated by electrochlorination, to neutralize 'disinfection by-products' by adding sodium bisulfite or sodium sulfite $[13,14]$.

\section{CASE STUDY}

In the case study presented here, an analysis of the annual operational cost of the two most widely used BWT methods (UV irradiation and electrochlorination) was carried out. The analysis involved an LPG vessel similar to the recent series 26xx of the shipbuilder Hyundai Heavy Industries Co. Ltd. Ulsan, Korea, with a capacity of 54.335 DWT, length $225 \mathrm{~m}$, and width 37 $\mathrm{m}$. The type and size of the ship was selected based on the fact that its size was close to the average size of the ships commonly used on ocean-going voyages and that ballast water loading/unloading frequency and quantities on LPG ships were between the corresponding frequencies and quantities on dry cargo ships and tankers.

Energy consumption for each method was estimated using publicly-available data on commercially available BWM systems shown in Table 1. It is noted that differences among various producers using the same method are insignificant, thus the average value was used. 
Table 1 - Systems used for the analysis of the total annual cost

\begin{tabular}{|c|c|c|}
\hline System & Manufacturer & References \\
\hline \multicolumn{3}{|c|}{ Electrochlorination } \\
\hline HHI EC (Hi Ballast) & Hyundai Heavy Industries, Korea & [15] \\
\hline Wärtsilä Aquarius EC System & Wärtsilä, Finland & [16] \\
\hline Samsung Purimar TM EC & Samsung Heavy Industries, Korea & [17] \\
\hline \multicolumn{3}{|c|}{ UV irradiation } \\
\hline HHI UV (EcoBallast) & Hyundai Heavy Industries, Korea & [15] \\
\hline Wärtsilä Aquarius UV System & Wärtsilä, Finland & [18] \\
\hline Alfa Laval PureBallast 3.1 (UV) & Alfa Laval, Sweden & [19] \\
\hline DESMI Rayclean TM (UV) & Desmi, Denmark & {$[20]$} \\
\hline Hyde Guardian Gold (UV) & Hyde Marine, US & {$[21]$} \\
\hline
\end{tabular}

The analysis was conducted by first calculating the cost of ballast water exchange using the sequential method in accordance with the D1 standards as a reference.

The aforementioned process includes the exchange of ballast during the ballast voyage and under favorable weather conditions, in accordance with the requirements of the $\mathrm{D} 1$ standard.

In these circumstances, an exchange requires 48.10 hours (the time and quantity used for the calculation are in accordance with the ship's "Ballast Water Management Plan" endorsed by the Recognized Organization on behalf of ship's flag as fully compliant with relevant articles of the Ballast Water Management Convention 2004 for 'Water ballast exchange condition' - Summary Table of Typical Sequences, p.26.) of pump operation time. The sequential method was chosen because it requires only one exchange of the total amount of ballast water as opposed to the dilution method, which requires three exchanges and, from the energy efficiency standpoint, it is less acceptable and thus was not taken into account. The proposed process assumes proper hull stability, bending moments within prescribed limits, and favorable propeller immersion during the exchange of ballast water at sea.

The total operational cost of exchanging ballast water in accordance with the D2 standards was then analyzed by comparing the two methods of secondary ballast water treatment: UV irradiation and electrochlorination. Predictive calculation was made for those systems, based on unit energy consumption of commercially available systems.

Finally, the annual operational cost of those methods implemented on the ship was estimated, presupposing 12 full trips per year.

\subsection{Methods}

The pump output power was calculated from the equation:
$P_{T O T}=P_{I N} \cdot f_{L C}=\frac{P_{O U T}}{\eta} f_{L C}$

where:

$P_{\text {TOT }}$ - total power $[\mathrm{kW}]$

$P_{I N} \quad$ - input power [kW]

$P_{\text {OUT }}$ - output power [kW]

$\eta$ - efficiency

$f_{L C} \quad$ - loading coefficient [\%]

The loading coefficient is defined as the ratio between the average load and the total load. The loading coefficient used in this case study was calculated by the shipyard in 'Analysis of the electric plant loads' of the mentioned series.

The electrical power was calculated as:

$A=N \cdot t$

where:

$A$ - electrical power [kWh]

$N$ - average power [kW]

$t$ - time [h]

The fuel oil consumption during one exchange of ballast water was calculated as follows:

$U=A \cdot S F O C_{\text {alt }}$

where:

$U$ - fuel oil consumption

$S F O C_{\text {alt }}$ - alternator specific fuel oil consumption

The engine specific fuel oil consumption $S F O C$ is $187 \mathrm{~g} / \mathrm{kWh}$. SFOC was taken into account along with the following ISO parameters:

- Inlet pressure to the turbocharger: 1000 mbar

- The temperature of air entering the turbocharger: $25^{\circ} \mathrm{C}$

- The temperature of the coolant in the air cooler: $25^{\circ} \mathrm{C}$

- Lower calorific value of fuel oil: $42,700 \mathrm{~kJ} / \mathrm{kg}$

- Tolerance: $5 \%$, at $100 \%$

- Efficiency of self-excited synchronous generator: $\eta=0.97$

- $\quad$ SFOC ${ }_{\text {alt }}$ alternator: $192.78 \mathrm{~g} / \mathrm{kWh}$ 
The cost of one ballast water operation was estimated using the following expression:

$C_{u}=U \cdot C_{j}$

where:

$C_{u}$ - total cost of one operation (loading or unloading)

$C_{j}$ - unit price of a ton of fuel oil

The unit price of a ton of fuel oil, used in accordance with the ISO 8217: 2010 RMG 380 standard, is $C_{j}=307.5$ US $\$ / \mathrm{mT}[22]$.

\subsection{Findings}

The findings for the present three cases are as follows:

a) Ballast water exchange applying sequential method
in accordance with D1 standard

For the given ship, the cost of fuel oil consumption was determined as follows:

Ballast pump (Qty): 2 sets

Output power (per 1 pump): $P_{\text {OUT }}=150 \mathrm{~kW}$

Efficiency: $\eta=94 \%$

Input power: $P_{I N}=159.57 \mathrm{~kW}$

Loading coefficient: $f_{L C}=0.8 \%$

Capacity: $Q=800 \mathrm{~m}^{3} / \mathrm{h}$

$P_{\text {TOT }}=\frac{P_{\text {OUT }}}{\eta} \cdot f_{L C}=127.66 \mathrm{~kW}$

Total power of one pump in operation:

$P_{\text {TOT1 }}=127.66 \mathrm{~kW}$

Total power of two pumps in operation:

$P_{\text {TOT2 }}=255.31 \mathrm{~kW}$

Total capacity of ballast tanks: $20,242.70 \mathrm{~m}^{3}$

Normal ballast condition: $17,741.00 \mathrm{~m}^{3}$

The average power $(N)$ in this particular sequential ballast exchange case is presented by $P_{\text {TOT1 }}$ pump power consumption, hence the electrical power used is:

$A=N \cdot t=6,141.44 \mathrm{kWh}$

The fuel oil consumption during one exchange of ballast water is as follows:

$U=A \cdot S F O C_{a l t}=1,183,946.8 g=1.184 \mathrm{mT}$

In this case the operational cost of one ballast water exchange using the sequential method was calculated at:

$C_{u}=U \cdot C_{j}=364.080$ US $\$$ b) Ballast water treatment according to D2 standard - UV irradiation

If it is necessary to load or unload the same quantity of ballast water, that is $17,741 \mathrm{~m}^{3}$, considering the average unit consumption of $0.11433463 \mathrm{kWh} / \mathrm{m}^{3}$, the total energy consumption amounts to $2,028.41$ kWh.

The fuel oil consumption required for one operation:

$U=A \cdot S F O C_{a l t}=391,036.88 g=0.391 \mathrm{mT}$

The total cost of one operation (loading or unloading) in accordance with the D2 standard using a UV system is:

$C_{u}=U \cdot C_{j}=120.233$ US $\$$

c) Ballast water treatment according to D2 standard electrochlorination

In case of electrochlorination and assuming the same quantity of ballast, that is, $17,741 \mathrm{~m}^{3}$, as well as considering the average unit consumption of $0.0494873 \mathrm{kWh} / \mathrm{m}^{3}$, the total energy consumption amounts to $877.95 \mathrm{kWh}$.

The fuel oil consumption required for one operation equals:

$U=A \cdot S F O C=169,251.201 \mathrm{~g}=0.169 \mathrm{mT}$

Finally, the operational cost of one operation in accordance with the D2 standard using an EC system is:

$C_{u}=U \cdot C_{j}==51.968$ US $\$$

When it comes to unloading, energy consumption is related to the energy required to drive the neutralizing agent injection pump, and it is of no importance in this case.

d) Estimated annual operational cost of ballast water treatment by using various processing methods

Assuming that a ship makes 12 trips annually, the estimated average annual cost for the above methods is shown in Table 2.

It can be noted that the sequential method in accordance with the D1 standard requires only 12 additional operations, as opposed to the UV and EC treatments in accordance with the D2 standard that require twice as many operations (24), also taking into account that energy consumption in EC treatment during unloading is of no importance.

Table 2 - The estimated average annual cost of ballast water treatment by using various processing methods

\begin{tabular}{||l|c|c||}
\hline \multicolumn{1}{|c|}{ Processing method } & Calculation of average consumption & Total annual cost (USD) \\
\hline \hline Sequential method in accordance with D1 standard & $12 \cdot 364.080$ & $4,368.960$ \\
\hline UV irradiation in accordance with D2 standard & $24 \cdot 120.233$ & $2,885.592$ \\
\hline $\begin{array}{l}\text { EC - electrochlorination in accordance with } \\
\text { D2 standard }\end{array}$ & $12 \cdot 51.968+12 \cdot 0$ & 623.616 \\
\hline
\end{tabular}


It is quite clear from the data presented that the annual costs for different BWT systems vary significantly. However, if compared with the overall purchasing and installation costs, these costs are minimal, even if taken at the whole life-cycle level. Therefore, from the shipowner's standpoint, it seems much more appropriate to pay more attention to purchase and installation costs than to operational costs. Such an extension of operational costs indicates that maintenance activities and related costs, i.e., those costs ensuring the proper operation in day-to-day work, should be borne in a way that will bring the operations up to the highest standards.

\section{CONCLUSION}

The International Convention for the Control and Management of Ships' Ballast Water and Sediments requires the processing of ships' ballast water in accordance with predefined standards. Various IMO-approved processing methods, with different power consumption levels, are offered by different manufacturers. Since power generation onboard is closely connected with quantities of fuel oil used, it is possible to compare the effectiveness of these methods based on fuel oil consumption.

The case study presented in this paper compares two most frequently used methods with operating costs borne by shipowners using the ballast water exchange method as a method commonly used before the full implementation of the Convention on all ships.

Apart from the costs arising from acquiring ballast water treatment plants and their installation on board, one of the most influential factors for the decision makers in shipping companies is the estimation of operating and maintenance costs. The analysis presented here for the reference ship shows that systems using electrochlorination may be almost five times more cost effective than those based on UV irradiation, and almost eight times more cost effective than ballast water exchange using the sequential method.

However, fuel oil consumption efficiency is not the only relevant factor in the decision making process. In addition to fuel oil consumption, other impacts, such as environmental load, reliability, and maintenance costs, have to be taken into account.

Therefore, the final decision in selecting the most suitable system is a combination of various factors, including the installation and maintenance cost of the system, the type and age of the ship, as well as the prevailing characteristics of the sea areas where a particular ship will sail.

Further research may focus on systems reliability with associated maintenance costs and assess conclusions set in this article; however, that will be required after several years of usage.

\author{
ALEKSANDAR VORKAPIĆ, doktorand ${ }^{1}$ \\ E-mail: vorkapic@pfri.hr \\ Dr. SC. RADOSLAV RADONJA ${ }^{1}$ \\ E-mail: radonja@pfri.hr \\ Dr. sc. DAMIR ZEC ${ }^{1}$ \\ E-mail: zec@pfri.hr, \\ ${ }^{1}$ Pomorski fakultet, Sveučilište u Rijeci \\ Studentska 2, 51000 Rijeka, Hrvatska
}

\section{EKONOMSKA UČINKOVITOST SUSTAVA ZA OBRADU BALASTNIH VODA UV ZRAČENJEM I ELEKTRO-KLOR- IRANJEM}

\section{SAŽETAK}

Stupanjem na snagu Međunarodne konvencije o nadzoru i upravljanju brodskim balastnim vodama i talozima iz 2004. godine zahtijeva se da brodovi obrađuju balastne vode $u$ skladu s propisanim standardima. Različite metode obrade balastnih voda na različite načine opterećuju brodsku električnu mrežu te time utječu na potrošnju goriva, energetsku učinkovitost i ekonomiju brodova općenito. U radu je prikazana analiza i usporedba ekonomske održivosti sustava usporedbom dviju najčešće korištenih metoda obrade balastnih voda na trgovačkim brodovima. Ekonomska učinkovitost postupaka UV zračenja i elektro-kloriranja, uspoređena je s ekonomskom učinkovitošću izmjene balastnih voda primjenom metode sekvencijalnog toka kao referentne. Ekonomska učinkovitost procesa mjeri se pomoću potrošnje goriva na brodu. Uzimajući u obzir moguće razlike u učinkovitosti zbog različitih izvedbi, ograničenja i pretpostavki okoliša, rezultati idu u prilog postupku elektro-kloriranja.

\section{KLUUČNE RIJEČI}

brodske balastne vode; brodski sustavi obrade balastnih voda; energetska učinkovitost brodova;

\section{REFERENCES}

[1] International Convention for the Control and Management of Ships' Ballast Water and Sediments (BWM) (homepage on the internet). No date. Available from: http://www.imo.org/en/About/Conventions/ListOfConventions/Pages/International-Convention-for-theControl-and-Management-of-Ships\%27-BallastWater-and-Sediments-\%28BWM\%29.aspx [Accessed $14^{\text {th }}$ Jun 2016].

[2] Stehouwer PP, Buma A, Peperzak L. A comparison of six different ballast water treatment systems based on UV radiation, electrochlorination and chlorine dioxide. Environ Technol. 2015;36(16): 2094-104.

[3] Briski E, Linley RD, Adams J, Bailey S. Evaluating efficacy of a ballast water filtration system for reducing spread of aquatic species in freshwater ecosystems. Manag Biol Invasions. 2014;5(3): 245-53.

[4] Tsolaki E, Diamadopoulos E. Technologies for ballast water treatment: a review. J Chem Technol Biotechnol. 2010;85(1): 19-32.

[5] Wu D, You H, Du J, Chen C, Jin D. Effects of UV/Ag-TiO2/O3 advanced oxidation on unicellular green alga Dunaliella salina: Implications for removal of invasive species from ballast water. J Environ Sci. 2011;23(3): 513-9. 
[6] IMO Ballast Water Management Documents. No date. Available from: http://www.imo.org/en/OurWork/Environment/BallastWaterManagement/Documents/ Table $\% 20$ of\%20BA\%20FA\%20TA\%20updated $\% 20$ April\%202016.pdf [Accessed 5 Jan 2018].

[7] MEPC $68^{\text {th }}$ session (homepage on the internet). No date. Available from: http://www.imo.org/en/MediaCentre/MeetingSummaries/MEPC/Pages/MEPC-68 ${ }^{\text {th }}$-session.aspx [Accessed 14 Jun 2016].

[8] Jung YJ, Yoon Y, Pyo TS, Lee S-T, Shin K, Kang J-W. Evaluation of disinfection efficacy and chemical formation using MPUV ballast water treatment system (GloEn-PatrolTM). Environ Technol. 2012;33(17): 1953-61.

[9] Oguma K, Katayama H, Ohgaki S. Photoreactivation of Escherichia coli after Low- or Medium-Pressure UV Disinfection Determined by an Endonuclease Sensitive Site Assay. Appl Environ Microbiol. 2002;68(12): 6029-35.

[10] Romero-Martínez L, Moreno-Andrés J, Acevedo-Merino A, Nebot E. Improvement of ballast water disinfection using a photocatalytic (UV-C + TiO2) flow-through reactor for saltwater treatment. J Chem Technol Biotechnol. 2014;89(8): 1203-10.

[11] US stance adds to owners' difficult choices (homepage on the internet). No date. Available from: http:// www.ballastwatermanagement.co.uk/news/view,usstance-adds-to-owners-difficult-choices_42523.htm [Accessed 22 Apr 2016].

[12] Matousek RC, Hill DW, Herwig RP, Cordell JR, Nielsen BC, Ferm NC, et al. Electrolytic Sodium Hypochlorite System for Treatment of Ballast Water. J Ship Prod. 2006;22(3): 160-71.

[13] Balaji R, Yaakob OB. Emerging Ballast Water Treatment Technologies: A Review (homepage on the internet) c2011. Available from: http://agris.fao.org/ agris-search/search.do?recordID=AV2012069353 [Accessed 22 Apr 2016].
[14] Werschkun B, Banerji S, Basurko OC, David M, Fuhr $\mathrm{F}$, Gollasch S, et al. Emerging risks from ballast water treatment: The run-up to the International Ballast Water Management Convention. Chemosphere. 2014;112: 256-66

[15] Hyundai Engine Machinery Division (homepage on the internet). No date. Available from: HHI http://www. hyundai-engine.com/ [Accessed 14 Jun 2016].

[16] Wärtsilä AQUARIUS ${ }^{\circ}$ EC Ballast Water Management System - brochure-o-aquarius-ec (homepage on the internet). No date. Available from: http://www.wartsila. com/docs/default-source/product-files/bwms-files/ brochure-o-aquarius-ec.pdf?sfvrsn=13 [Accessed 14 Jun 2016].

[17] BWMS PURIMAR Brochure (EN) (homepage on the internet). No date. Available from: http://www.shipcs. com/Upload/customer/BWMS\%20PURIMAR\%20Brochure(EN).pdf [Accessed 14 Jun 2016].

[18] AQUARIUS ${ }^{8}$ UV - brochure-o-aquarius-uv (homepage on the internet). No date. Available from: http:// www.wartsila.com/docs/default-source/product-files/ bwms-files/brochure-o-aquarius-uv. pdf?sfvrsn=13 [Accessed 14 Jun 2016].

[19] Alfa Laval (homepage on the internet). No date. Available from: http://www.alfalaval.kr/ [Accessed 14 Jun 2016].

[20] RayClean | DESMI - Proven technology (homepage on the internet). No date. Available from: http://desmioceanguard.com/rayclean-(2).aspx [Accessed 14 Jun 2016].

[21] Ballast Water Management Technology | Hyde Marine (homepage on the internet). No date. Available from: http://www.hydemarine.com/index.php [Accessed 14 Jun 2016].

[22] BUNKER INDEX: Price Index, News and Directory Information for the Marine Fuel Industry (homepage on the internet). No date. Available from: http://www.bunkerindex.com/prices/neurope.php [Accessed 28 Feb 2017]. 